\title{
7 Who wrote CEDAW?
}

\author{
Ellen Chesler
}

\section{Introduction}

Educated in London in economics and law, Annie Jiagge became the second woman lawyer in the newly independent state of Ghana, and the second woman in Africa to serve as a justice of the courts. In 1962, she came to New York to represent her country at the United Nations Commission on the Status of Women, or in UN parlance, the CSW. Five years later, as rapporteur for the group, she stayed up one night and crafted together a draft of the Declaration on the Elimination of Discrimination against Women, known as DEDAW, a document that would help transform global understanding of the issue of sex discrimination and provide a framework for a binding women's rights treaty a decade later. ${ }^{1}$

DEDAW represents the UN's first attempt to define the meaning of women's rights as fundamental human rights and do so expansively. The agreement claimed that discrimination against women is "unjust and constitutes an offence against human dignity." It established the legal principle of equal protection for women, when only a few countries had done so. And it demanded that "all appropriate measures" be taken to abolish prejudice, not just in law, but also in customs and practices based on the "idea of women's inferiority."

The UN General Assembly had bold aspirations for this undertaking. It endorsed the document expressing a confidence, radical for its time, that women's advancement is not just a moral obligation but also a necessary condition to secure global progress: "The full and complete development of a country, the welfare of the world, and the cause of peace require the maximum participation of women as well as men in all fields," the 1967 preamble to DEDAW proclaims in language credited to Annie Jiagge. ${ }^{3}$

Leticia Ramos Shahani joined the UN in 1964 as a young editor for the Secretariat in New York, where she worked on general human rights matters and then transferred to the division overseeing the advancement of women. A graduate of Wellesley College, Shahani, had also earned a doctorate in comparative literature at the Sorbonne, but she then changed course and decided to follow in the tradition of her father, a prominent diplomat from the Philippines. Just a few years later, in 1968, after the tragedy of her husband's sudden death, Shahani left her staff job at the UN and returned home to seek family assistance with the care of her three young children. In short order, however, she was back, representing her country as a diplomat at the CSW, the organization she had once staffed. She soon landed as chair of the body and became a rising star in the UN system.

The CSW had been asked to create a binding human rights instrument elaborating on the declaration. Shahani came up with a draft. This effort, after protracted

DOI: $10.4324 / 9781003036708-7$ 
negotiation, produced the Convention on the Elimination of all Forms of Discrimination against Women (CEDAW), an international bill of rights for women, which was adopted by the General Assembly in 1978 and formally signed by member states in $1980 .^{4}$

The convention enjoys a robust and diverse commentary, but it lacks a thoughtful history that identifies its principal authors, analyzes their personal and political motivations, explains the complex circumstances in which they worked, and engages with the many arguments arrayed for and against it. ${ }^{5}$

Finding the sources to construct that narrative, however, is a challenge. The archives are tragically sparse. An early proposal to fund a formal historical records office at the UN foundered on opposition from Americans concerned about costs and from Soviets worried about objectivity. Formal standards were never created for preserving the background correspondence and documentation that would have illumined the typically opaque transcripts that survive from official public proceedings. In the case of CEDAW, moreover, this institutional failure was compounded when the UN Division for the Advancement of Women, having moved to UN headquarters in Vienna during the late 1970s at the time CEDAW was negotiated, later returned to New York, and boxes of its records were unaccountably lost in transit. ${ }^{6}$

Only two prior analyses I could identify draw on primary sources or on interviews with participants in the drafting of these documents. The late American human rights activist and scholar, Arvonne Fraser, first wrote briefly on the subject. ${ }^{7}$ The Dutch legal scholar Lars Rehof later mined incomplete records of the final CEDAW negotiating sessions available in the UN Library in Geneva for a Travaux Preparatoire. To the extent possible, Rehof identifies various state party contributions to the long and intense debate over the document's evolving structure and language and concludes that the animating principles and substantive approaches of the 1967 declaration and of the earliest CEDAW draft fundamentally shaped the outcome. Neither work, however, explores the women behind these drafts or investigates what informed their thinking and inspired their activism. $^{8}$

This chapter begins an overdue effort to that end. It establishes necessary historical context and then zeroes in on the biographies of the two women identified as principal architects of the declaration and the convention respectively, Annie Jiagge and Leticia Shahani. Passing reference is made to others, such as Princess Ashraf Pahlavi, who energized and financed the UN's women's rights projects at the UN in these years, before the 1979 revolution in Iran sent her family into exile. The contributions of other important diplomats and civil society advocates from Western Europe, the Americas, and the Soviet bloc are mentioned only briefly. Within the confines of a single chapter, I offer only a snapshot of events that deserve an even richer portrait.

\section{Getting to a declaration on women's rights}

As the UN grew in membership, newly independent states lacked the capacity and resources, or the will, to enforce early agreements on gender equality. The 
need for a more robust approach became clear, as did the recognition that formal principles of political and civil equality would not be sufficient to address the economic obstacles facing women or to liberate them from patterns of discrimination with deep social and cultural roots. In 1963, at the urging of 22 developing world countries and the Soviet bloc, the General Assembly called on the CSW to prepare a declaration modelled on the UDHR that would address these many challenges. Drafting began at the commission's next scheduled meeting in Tehran in 1965, and a final document reached the General Assembly two years later. ${ }^{9}$

Twenty-three countries comprised the CSW membership at this time. The budget constrained body convened bi-annually in these years, and occasionally met abroad where a local host would cover costs. Princess Ashraf Pahlavi, twin sister of the Shah, presided as chair that year, representing the Iranian government, which had launched its "White Revolution" two years before, a program of social and economic reforms that promised to increase literacy, reform land ownership, grant long demanded worker's rights, and extend the franchise and the right to run for office to women. Contempt for this effort from the Ayatollah Khomeini, who likened women's voting to prostitution, was a principal factor in his expulsion from the country and fuelled the opposition movement he led from exile for the next 15 years. Rising tensions in Iran cast their shadow on the CSW proceedings, but in an ominous forewarning of the conservative religious alliance that would burden the UN women's agenda far into the future, opposition to the CSW agenda also came from Catholic countries like Mexico, even as its representative, Marina Lavelle Urbino, rotated into a term as CSW chair. ${ }^{10}$

According to Arvonne Fraser, working papers were prepared for the declaration's drafting committee by Marina Urbino, Annie Jiagge, and Zofia Dembinska of Poland. But differences arose quickly within the group over basic questions of legal philosophy and reach, including what should have been straightforward - the question of equal protection under the law. Inscribed in the UN charter and in the UDHR, that basic equality principle was again front and center in the two overall UN human rights conventions that had been hammered out over many years - the International Covenant on Civil and Political Rights (ICCPR), and the International Convention on Economic, Social and Cultural Rights (ICESCR) - both of which would finally reach the General Assembly for approval in $1966 .^{11}$

But what would equal protection mean in circumstances where men continued to serve as legal guardians and heads of household? How would the formal claim of legal equality address the special burdens of women struggling to balance obligations of work and family? What would its impact be on developed countries where protective labor laws had already established minimum wages, maximum hours, and other ostensible safeguards for women workers?

Debate among the delegates was serious and intense. There were fractures across geographic and ideological divides, east-west, and north-south. Further work was put off until the next scheduled CSW meeting in 1967. Members of an expanded drafting committee were then invited to present alternative texts in writing, with the intent of avoiding further protracted discussion. Official proceedings were limited to up or down votes on proposed amendments. 
In this manner, for example, a proposal was made to water down the document by suggesting that it "modify," rather than "abolish" discriminatory laws, but the stronger language prevailed. Where differences could not be resolved - as in how exactly to define what constitutes "discrimination" against women - the meaning of the term remained ambiguous. In one of history's great ironies, Afghanistan's delegate introduced the idea that "temporary special measures" could compensate for historic patterns of discrimination without violating the larger equality principle, therein introducing the concept that has since inspired national affirmative action policies that address race and gender. Absent agreement, the matter was tabled, as was another disputed question — whether to condemn the practice of female genital cutting as a rights violation. ${ }^{12}$

Credit for sorting through differences over content and language, and for putting forward a coherent and straightforward final text, went to CSW rapporteur, Annie Jiagge of Ghana. The final draft of the declaration she crafted follows the structure of the UDHR and includes the lofty preamble quoted above and eleven short articles. There is no equivocation over the basic tenets of the agreement: to "abolish" discrimination; to establish a strict legal standard of equal protection; to educate public opinion; and to "direct national aspirations" to eliminate prejudice.

The document reprises earlier CSW actions from the 1950s on suffrage, the right to hold public office, nationality rights, civil law governing marriage and divorce, and education, and adds clarifying detail. Claiming no prejudice to the "unity and harmony of the family, which remains the basic unit of society," for example, Article 6 spells out women's rights in the home to include equality in legal capacity, property and inheritance, child custody, and freedom of movement. Article 8 addresses prostitution and trafficking in women, presaging a later and more forceful engagement by the UN with the problem of sexual violence. Article 10 addresses the principle of non-discrimination in employment and enumerates specific recommendations, such as equal pay for equal work, paid maternity leave, and childcare, creating an ambitious public policy framework. ${ }^{13}$

\section{Who was Annie Jiagge?}

Annie Ruth Baeta Jiagge was born in 1918, in Lome, Togoland, now the Republic of Togo, one of four surviving children of Henrietta and Robert Domingo Baeta, a couple of mixed African and Brazilian/Portuguese lineage. Her mother was a schoolteacher, her father, a minister of the Presbyterian Church, educated in Germany, which had ceded the colony to France. As a girl demonstrating considerable educational promise, she was sent to live with her maternal grandmother in Accra, the capital of neighboring British Togoland, now Ghana, where better English-speaking schools were available. Widowed as a young woman, the grandmother, Barbara Sedode, had become a wealthy and influential merchant, trading local agricultural products for European imports.

The young Jiagge at age 15 entered Achimota College, an elite secondary institution, from which she graduated four years later with a teaching certificate, permitting her to work at the primary school she had attended, the Evangelical 
Presbyterian School for Girls in the coastal town of Keta. She soon became head of the school, but with longstanding aspirations to continue her education, and with loans secured by her mother, she left for London in 1946, after the war in Europe ended, having been admitted to the London School of Economics and Political Science. The doors of the institution were opened for the first time to male students from the colonies and to refugees from continental Europe, but there were only three other women in her class, two British and one from India. Jiagge later recalled that she had struggled to succeed as a woman of colour in that setting. Whenever she complained, however, her male friends would strengthen her resolve by encouraging her to quit and study fashion in Paris instead. She persevered, earned a bachelor's degree in 1949, and was called to the Bar at Lincoln's Inn a year later.

Alone in London, Jiagge found a welcoming community at the Young Women's Christian Association (YWCA), an institution to which she remained devoted for the remainder of her life and long credited with having shaped her thinking about the injustices suffered by women and girls. She travelled through continental Europe, the Middle East, and India during college and in the years thereafter, as a member of the executive board of the international YWCA, which also became an important civil society partner on women's issues in the early years of the UN.

Back in Ghana as a young barrister, Jiagge established a local YWCA outpost after she was engaged to represent a young woman from the countryside who had been raped and robbed while seeking shelter. Through her campaign to raise awareness of this widespread problem, and to secure government support for a hostel, she met Kwame Nkrumah, who would soon become president of Ghana, the first British colony in Africa to gain independence in 1957. Like her, he had attended Achimota College but then went to the United States to complete his university degree.

In 1953, at age 35, still eager for a family of her own, Annie Baeta married Fred Jiagge, a local businessman, whom she had known years earlier at Achimota. Unable to conceive a child of their own, they adopted a son and, as had been her grandmother's custom, also raised several girls from rural villages in their household and provided them education. Seeking more manageable hours than her demanding legal practice allowed, Jiagge joined Ghana's courts as a magistrate that year; became a circuit court judge in 1959, a High Court judge in 1961, and a member of the Court of Appeal, then the highest court in the land, in 1969, where she presided as president from 1980 until her retirement three years later. Family and faith remained a central part of her life. ${ }^{14}$

In recent years, a body of scholarship has emerged examining the role of women in the shaping of African nationalism. The biographical elements of Jiagge's life follow the principal contours of this work, which generally holds that Europeans tried but did not fully succeed in introducing gender hierarchies into many African societies long distinguished by a tradition of complementarity between men and women in many facets of life that extended from the household into economic activities like farming and trade, and into civic and political affairs. This was especially true among elites, where authority in the family was commonly shared by husband and wife. Jiagge's family replicated this model. 
Kwame Nkrumah rose to power in the 1950s with broad-based support across socio-economic classes and trades - those educated and those not - but also with special attention paid to women and young people, whom he organized through such traditional networks as markets, voluntary associations, and places of worship. One historian describes women as "the backbone" of Nkrumah's revolution. Having gained the right to vote under British rule, women became active in political parties in the run up to independence and were invited to stand for local office. In the first years after independence, ten women were also elected to the new national parliament, which debated social issues such as banning nudity, outlawing bigamy, and bringing marriage under civil rather than customary law. ${ }^{15}$

Nkrumah sought to make Ghana the model for a modern Pan-Africanism that also attracted prominent black Americans then in the throes of the U.S. civil rights movement, including W.E.B DuBois and Bayard Rustin, both of whom attended Ghana's historic Conference of Independent African States in 1958, which was meant to build unity and consolidate ties among countries newly freed from imperialism. The utopian vision set forth there incorporated egalitarian economic and social principles across class, cultural, and gender lines and put Ghana on a path that Nkrumah defined as non-aligned socialism. ${ }^{16}$

Ghanaian historian, Adwoa Opong, says this gathering inspired the Ghana Organization of Women, then the country's leading voluntary association, to convene a "Conference of Women of Africa and African Descent" that would examine "the struggles of Negro [sic] women across the continent and in the diaspora" and establish conditions for women's "emancipation, unity and advancement."17 The meeting of 150 women convened in July of 1960. Representing the United States, among other notable black women, was Pauli Murray, a Howard University trained lawyer, whose innovative legal scholarship on race discrimination had contributed to Thurgood Marshall's arguments in his direct challenge to school segregation in the landmark case of Brown v. Board of Education in 1954.

Jiagge's speech to the conference offers a rare window into her thinking at the time. Ghana's women enjoyed few legal protections despite the prominent roles they played in agriculture, commerce, and civic life. "Only lip service is paid to the saying that a woman's place is in the home... there is hardly anywhere outside the home where she hasn't another special place," she observed, while acknowledging that competing systems of civil and customary law ceded full control to men over marriage, child custody, property, and inheritance. ${ }^{18}$ Once women married, therefore, they suffered what she later referred to as "civic death." Other speakers addressed additional barriers, especially in rural villages, where whatever authority women may have enjoyed, they were denied education, expected to bear many children, and valued primarily as mothers. ${ }^{19}$

Pauli Murray used this platform to educate conference participants on the establishment of the UN CSW and its mandate to create universal standards for women's rights. She encouraged greater participation in the body and closed with a rousing peroration:

...the problems of women everywhere, without respect to color, or to nationality, or to religion, are common problems, and they must be solved many 
times through common agencies, and when we have finished unifying the continent of Africa, we will then have to unify the world, and this will be done through the United Nations. ${ }^{20}$

Murray had been lured to Ghana by pan-African idealists including DuBois and his wife, who would soon lose confidence in U.S. institutions and become expatriates. Her experience, however, was disappointing. She taught at the newly created Ghana School of Law for a year, but immediately grew skeptical of Nkrumah's drift away from democracy - his surveillance and silencing of critics, censorship of the press, and declaration of one-party rule. And while she understood the allure of socialism for countries whose wealth had long been extracted by Europeans, she correctly predicted that Africans who rejected democratic practice and free enterprise would become pawns of the Cold War. Murray also questioned Nkrumah's support of women's rights, which she saw as a political calculation rather than a genuine commitment. He would soon consolidate all civil society organizations, including independent women's groups, under strict government authority. ${ }^{21}$

I could find no evidence whether the two women again crossed paths, even as their interests continued to converge. Jiagge joined the CSW in 1962, just as Murray returned to the U.S. and became a member of John F. Kennedy's U.S. Commission on the Status of Women at the invitation of its chair and her longtime friend, Eleanor Roosevelt. In that forum, she introduced the legal concept of "Jane Crow" for which she became famous, to illustrate the parallels she saw in how to confront sex and race discrimination. Her arguments helped persuade second wave U.S. feminist Betty Friedan to establish the National Organization of Women as an NAACP-like advocacy organization seeking legal reforms for women, and years later provided Ruth Bader Ginsburg, then a young civil liberties lawyer, with the case she made to claim equal rights for women using the equal protection clause of the $14^{\text {th }}$ Amendment to the U.S. Constitution. How Pauli Murray may have also influenced Jiagge's thinking in these years is worth considering, as is the opposite proposition - that Murray's experiences in Africa may have shaped her new resolve about the intersections of rights of race and gender. Further research seems essential. ${ }^{22}$

What we do know is that by education, professional training, and lived experience, Jiagge was well prepared in her own right to understand the multiple constraints that burden women and to seek their resolution in law and public policy. In 1976, she assembled her thoughts on the "Exploitation of Women in Third World Perspective" for the Ecumenical Review, a World Conference of Churches publication, summarizing "the staggering evidence on the deprivation and degradation of all kinds suffered by women all over the world on account of their sex." ${ }^{23}$ She condemned enduring traditions of male privilege but also offered confidence that education, legal reform, and birth control would liberate women. $^{24}$

The article reinforces the view of family members and former colleagues interviewed for a recent biographical project in Ghana, who spoke of Jiagge's exceptionally good nature and of her deep religious conviction. Both attributes could 
only have served her well in contentious UN forums and as she navigated tortuous political currents at home. Temperament may have been her saving grace.

Jiagge survived the military coup that sent the Nkrumah into exile in 1966, an action in which the U.S. Central Intelligence Agency has since been implicated. She then became the choice of Ghana's generals to lead a high-profile investigation of corruption in his regime, an exercise that produced multiple charges and prevented many of the defendants from participating in politics, until it was reversed a decade later. Throughout this turmoil, she continued to represent Ghana at the CSW, and in 1968 was elected as its chair. ${ }^{25}$

At home, she went on to establish Ghana's Council on Women in Development - an early example of the "national machinery" the UN was then encouraging. The work of this organization later inspired Esther Ocloo, an Achimota school friend who had prospered as an entrepreneur, to travel with her to the UN women's forum in Mexico City in 1975, where they helped launch the network that became Women's World Banking, a pioneer in the micro-credit space that continues to work today with financial institutions in 32 countries, providing loans to some 24 million small entrepreneurs around the world, 80 percent of whom are women. These institutions, however, proved no immediate protections against Ghana's notorious generals, who ruled the country for nearly two decades with a heavy hand, inflicting successive reigns of terror and licensing sexual assault, especially on market women, whom they tried to hold responsible for their own failed economic policies. ${ }^{26}$

Jiagge last returned to the UN in 1980, at a moment when democracy in Ghana was briefly restored, and she took part in the formal passage of CEDAW. During the decades of revolving military rule, she remained on the appeals court, handling commercial and domestic disputes, some involving women's inheritance, with no evidence of any involvement in politics. When democracy was permanently restored, however, she was chosen to serve on the commission that wrote the country's new constitution. The 1992 document guarantees the:

enjoyment by every person of fundamental human rights and freedoms, including freedom of speech, freedom from arbitrary arrest and detention, freedom of assembly and association, including the freedom to form political parties, women's rights, worker's rights and the rights of the handicapped. ${ }^{27}$

The following year, Jiagge accepted the invitation of UN Secretary General Boutros Boutros-Ghali to join an advisory planning group for the Fourth World Conference on Women planned for Beijing in 1995, which she was then too ill to attend. At her death, BBG paid tribute to Jiagge as "a driving force" in the advancement of women's rights, known for her "determination and ingenuity." 28

\section{Leticia Ramos Shahani and the drafting of the CEDAW}

In 1968, the UN marked the 20th anniversary of the UDHR with a high-profile inter-agency conference in Tehran hosted by the Human Rights Commission. Annie Jiagge attended in her capacity as CSW chair. Leticia (Letty) Shahani, 


\section{Ellen Chesler}

having left the UN after her husband's death, was not present, but a report she had written as her final staff assignment was among the official documents prepared for the event. It made the case for linking women's rights to community development. $^{29}$

The Tehran meeting is now understood as a pivotal moment in the revision of human rights discourse to place greater weight on economics. Shah Reza Pahlavi set the tone in plenary remarks that boldly endorsed a revision in rights categories, privileging economic and social rights while leaving the matter of civil and political protections opaque, in what some saw as a thinly veiled rationalization for cracking down on opponents of his modernization efforts, but also on left-of-center antagonists of his aristocratic tendencies. ${ }^{30}$

In this context, women's rights provided a rare subject of agreement. The conference endorsed CSW recommendations to expand the UN's women's legal rights project and called for a unified effort across all agencies to advance women. Plans were outlined for greater investment in rural agriculture, where women's work remained informal, and for the development of the mechanism to support family planning that later became the UN Fund for Population Assistance (UNFPA). Countries were encouraged to set up national commissions on the status of women, and pledges were made to open more senior positions to women in the UN system, The General Assembly endorsed these objectives two years later. Subsequent provisions were also made for periodic, voluntary reporting on implementation of DEDAW by member states. Work on a proposed binding convention, however, languished, as Western Europeans and Americans came under the sway of conservative governments concerned about rising costs at the UN and averse to burgeoning human rights obligations. ${ }^{31}$

Back in Manila, Shahani became Assistant Secretary for the UN in the Philippine Department of Foreign Affairs and set up a national women's rights commission. She was also appointed to serve as a delegate to the CSW. With demonstrated facility in producing UN documents, she quickly became the group's choice to take over as rapporteur and within a few years to become chair. ${ }^{32}$

Born into an elite family in 1929, Shahani was the second of three children of Narcisco Ramos, a crusading lawyer and journalist, who became a diplomat in the early days of independence and ultimately the country's Secretary of Foreign Affairs. Her mother Angela Valdez-Ramos, a teacher and early advocate for women's suffrage, was aunt to President Ferdinand Marcos. Shahani's older brother, Fidel (Eddie) Ramos, to whom she was very close, was head of the country's constabulary police under Marcos, a position that put him in charge of arresting political dissidents when martial law was declared, a fact that did go unnoticed by skeptics of his sister's women's rights advocacy. He resigned in 1986, when he then led the popular movement to restore democracy under Corazon Aquino, before becoming president in his own right in 1992. ${ }^{33}$

Narcisco Ramos was a deputy in the Philippine embassy in Washington where his daughter attended her final years of high school and then went onto Wellesley. He then became ambassador to India, where, at age 22, she met and fell in love with Ranjee Shahani, a Karachi born intellectual, 25 years her senior, who had studied in France and lived for three decades in England. His many published 
works, ranging from a reflection on Shakespeare, to a popular portrait of Gandhi, to a volume on Indian sexual practices, earned him stature in elite British literary circles and appreciations from such prominent writers as H.G. Wells and Havelock Ellis. ${ }^{34}$

They married in 1962, following a decade-long courtship, once she had completed her doctorate, and he had divorced an estranged first wife. According to their daughter, Lila, the unconventional marriage was never fully accepted by her mother's family, which accounted for their decision to start a new life together in the United States, where they both initially found university teaching positions. He then died suddenly six years, and three children, later. Lila, the youngest, was still a toddler. Her mother never lacked for suitors thereafter, in Lila's memory, but buried her grief and her passions in her family and, perhaps, more completely in her work. ${ }^{35}$

In her first job at the UN, Shahani was fortunate to find a mentor in Julia Henderson, a former Wellesley professor of economics, who came to the institution in its early years and served as inaugural Director of the Bureau of Social Affairs. Shahani remembered Henderson as an eloquent advocate for "the social aspects of development and the need to look after the welfare of the human being and marginalized groups," and, in this regard, as an "intellectual" whose vision was not realized until the 1990s, when Cold War antagonisms diminished, and opportunities emerged to integrate social and economic concerns into a comprehensive human security framework. ${ }^{36}$

When Shahani transferred to the section of the Secretariat staffing the CSW in 1966, she gained a second valuable superior in Margaret Bruce, a British born veteran of the UN's early days, from whom she gained practical experience in how to prepare "thorough and precise" documents in clear language meant to inspire consensus. She credited this training for her later successes in drafting agreements, navigating the UN bureaucracy, and overcoming the resistance she encountered from the many men who still considered women's issues "a joke," as she put it. ${ }^{37}$ Shahani may well have taken away a third lesson from her time at the $\mathrm{UN}$ - that she would be far more influential as a delegate in her own right than as a staffer. In 1966, she passed the Philippine foreign service exams that qualified her for the position she later assumed when she returned home. ${ }^{38}$

Unbowed by intellectual challenges or by strong political headwinds, Shahani first took it upon herself to prepare a working draft of a women's rights convention in 1972. She leaned on her own UN experience but also called on Minerva (Mina) Falcon, then a young lawyer on her staff in Manila, who would subsequently become a prominent ambassador in her own right, with postings in Turkey, Germany, Switzerland, and Canada. In a recent interview, Falcon observed that sheer will to advance her own career made up for a lack of formal training in human rights at the time. ${ }^{39}$ With the benefit of youthful innocence and pluck, she simply assembled and referenced every relevant document she could find, a daunting research task in an era before the Internet, indeed, before computers.

Using DEDAW as a framework, she filled in essential details from printed material in Mrs. Shahani's possession and consulted other human rights instruments and national constitutions. She then produced a draft on a manual typewriter and 


\section{Ellen Chesler}

made copies on carbon paper, in what she remembers as a tedious and cumbersome process. Especially important was the 1968 International Convention on the Elimination of Race Discrimination (ICERD), from which she derived an expansive definition of sex discrimination, like race, as a problem deeply embedded in cultural circumstances that formal changes in the law would not alone eliminate. This insight helped resolve the conundrum that had kept DEDAW's framers from clearly defining the term. Human rights scholars, Marsha Freeman and Christine Chinkin, observe the significance of CEDAW's distinction between formal equality in the law and substantive equality in everyday life, where male privilege has for so long been taken for granted, and women's inferiority assumed-a persistent pattern that public policies then often unconsciously replicate. The treaty extends state action to private behaviors in the community, business, and the family. Sex discrimination, distinct from race, is especially intractable in this respect because it occurs within families bonded by ties of genuine affection. ${ }^{40}$

Falcon also identified dimensions of her own upbringing that shaped her thinking. As was true in the circumstances that produced Annie Jiagge. Filipino women across class lines traditionally enjoyed influence within their families and communities and routinely balanced formal work and family obligations. Her own mother, like Shahani's, was a teacher. Universal English language education through the secondary level became available to boys and girls after the United States wrested the colony from Spain at the turn of the twentieth century. This produced a skilled female workforce and opened doors to university training and professional opportunities for women as well. Yet virtually no laws existed to address bias and secure women's rights, and a politically powerful Catholic Church, the legacy of Spanish rule, regulated family law, dictating the terms of marriage and divorce, and prohibiting birth control and abortion. Falcon deeply admired Shahani, whose family came from the country's Protestant minority, for her courage in taking on these challenges, and for her intellect, values, and diplomatic skill. ${ }^{41}$

As Shahani herself would tell the story on many occasions thereafter, she returned to New York, with a preliminary CEDAW draft in hand, having never mentioned the matter to her superiors. This was a serious breach of protocol. At CSW meetings that year, she found only one willing co-sponsor in Tatiana Nikolaeva, a respected senior member of the Russian Foreign Ministry, who was also willing to sign on without formal consultation and approval from her government. Consorting with Russians, however, constituted a second grave infraction for a U.S. aligned Filipino at the time.

The maneuvers resulted in what Shahani later characterized as a "kilometric" response from then Secretary of Foreign Affairs, Carlos P. Romulo, another veteran diplomat who had represented the Philippines at the UN's charter meetings and was a long-time colleague of her father. This personal relationship may explain why Romulo accepted her characterization of the document she had put together as an "unofficial working paper" and withdrew his objections. It may, however, also explain her subsequent posting in Bucharest in 1975, as her country's first ambassador to Soviet satellites, Romania, Hungary, and East Germany-a challenging job but hardly a plum assignment, in those dark and lean years 
under the dictatorship of Nicolae Ceausescu, with only one apparent advantage. It put her close to Vienna, where the UN Secretariat's Division on the Advancement of Women had relocated at the invitation of Austrian Secretary General Kurt Waldheim. In 1978, however, she became Ambassador to Australia, a happier place and an important Philippine trading partner that was also absorbing huge numbers of Filipino workers. But if was very far away from the UN. ${ }^{42}$

Meanwhile, the UN had designated 1975 as International Women's Year and organized a landmark conference in Mexico City that would begin to flesh out policy and programmatic agendas in the hope of realizing concrete gains for women - the first of four such gatherings that would culminate in Beijing 20 years later. For many years, the reputation of this event suffered from selective representations of what happened there. Journalists who covered the official sessions and the parallel civil society forum constructed a tumultuous narrative of conflict between first world feminists, whose concerns they treated contemptuously, and grassroots women from the developing world, whose victimization, however worthy of redress, they viewed as hopelessly intractable. A first generation of scholars then accepted these characterizations at face value.

A recent re-interpretation by the historian Jocelyn Olcott, however, takes a different view, emphasizing the ingenuity of the seasoned diplomats in charge of the conference, who were able to craft an agenda sensitive to the geographic, cultural, and class diversity of the assemblage. ${ }^{43}$ Helvi Sipila of Finland, the first woman to be appointed as a UN Assistant Secretary General, served as presiding official at Mexico City, and Leticia Shahani worked closely with her as CSW chair. Ashraf Pahlavi provided critical funds for the event but kept a low profile.

As a Filipino, Shahani also belonged to the new and powerful alliance within the UN system - the Group of 77 non-aligned Nations (G77) — which had recently negotiated a document known as the New International Economic Order (NIEO) committing international institutions and donor countries to expand resources for development and secure conditions for human rights to flourish. The Mexico City conference incorporated these priorities in its outcome document and left institutional structures in place to help achieve them: INSTRAW, the UN training and research institute to advance women that has since provided valuable research and data to bolster advocacy; UNIFEM, a dedicated financing arm within the UN's development apparatus; and CEDAW, which the CSW was instructed to finalize. ${ }^{44}$

Working groups on CEDAW that included interested governments, specialized agencies, and NGOS, had been meeting since 1974. The negotiation process replicated procedures put in place years earlier in Tehran. Comments were accepted in writing and then consolidated into drafts displaying bracketed alternatives in language that was voted up or down. Sensitivities were high, and reservations extensive, give the ambitious reach of the document into matters governing family life, long controlled by religious or customary law.

The draft went from the CSW to the Economic and Social Council of the General Assembly, and then onto the main body itself in 1977, which circulated a largely favourable analysis signed by the Secretary General. ${ }^{45}$ With many specific matters still unresolved, however, multiple subsequent meetings were necessary 
during the next two years to discuss and revise the substance and make final stylistic and technical changes before formal adoption by consensus in December of 1979, with only two countries at the time-Iraq and Morocco-expressing formal reservations. Plans were made for a signing ceremony at the second World Conference on Women scheduled for July of 1980 in Copenhagen. ${ }^{46}$

The treaty as adopted consists of a short preamble that largely follows the language of DEDAW in defining discrimination and in locating women's rights within larger aspirations for self-governance and for development inspired by the anti-colonial, independence movements of the day. The Philippine draft had not provided a preamble. A version first suggested by the Soviets was largely replaced after extensive negotiations, especially among Westerners who preferred Annie Jiagge's simpler, logical approach, and more elegant language. ${ }^{47}$

The substance that follows also tracks but expands considerably upon the declaration. Five articles seek to define discrimination and provide for concrete measures to address it through a positive, action-oriented government responseyet one with the flexibility to accommodate countries of vastly different economic and social circumstances. Much is made of the need for innovation beyond conventional legal remedies to confront the reality of attitudes and prejudices deeply embedded in families and cultures. Surviving from the Philippine draft, after extensive discussion and changes in wording, is the concept of granting temporary special privileges to women as amends for the past, which never made it into DEDAW. This includes an explanation of how to distinguish such interventions from permanent protective measures that segregate women and limit their opportunities. ${ }^{48}$

Ten more articles spell out "all forms of discrimination" in detail and catalogue necessary responses across sectors, including politics and civic life, education, employment, finance, agriculture, health care, sports, culture, the media, and criminal codes governing prostitution and sex trafficking. Article 11 on employment calls for legislation to guarantee equal pay and paid maternity leave. Article 12 obligates national governments to provide equal access to health care, including family planning, with the specification added by India that these programs include information and counselling, as well as technical services. These were ideas still far ahead of their time.

The most controversial section of the document, incorporated into Article 16, spells out the meaning of discrimination in marriage and family relations and calls for shared responsibility in decisions about age and consent in marriage and in the planning, spacing, rearing, and betrothal of children. Special emphasis is given to the "paramount" interests of children and extends protections to those born in and out of wedlock. Originating in the joint Philippine/USSR draft, these concerns are joined together with formal legal provisions for guardianship, for ownership and distribution of property, and for other aspects of personal legal capacity long denied women, such as choice of family name and of profession or occupation. Reservations on this article during the treaty's ratification would be even more extensive than during the negotiation, especially from Muslim majority countries with objections all around, but most emphatically to the protection of single mothers. ${ }^{49}$ 
Article 17 sets the terms for ratification of the treaty and addresses its implementation, matters the Philippine draft had left unattended. It calls for the election of a geographically balanced committee of 23 experts "of high moral standing and competence in the field," who would serve four-year terms and hold annual meetings to review enforcement by state parties on a revolving schedule. These procedures followed those established for ICERD and largely reflected the concerns of European, American, and Iranian delegates, who while cool to the idea of a treaty at the start, then fought to insure its rigorous execution. The change reflected the new emphasis on human rights and global development in Jimmy Carter's foreign policy. The Carter administration had established a women's initiative at the U.S. Agency for International Development run by Arvonne Fraser, then a prominent Democratic party activist and wife of a Minnesota congressman. She, in turn, recommended Koryne Horbal, who negotiated CEDAW as U.S. representative to the $\mathrm{CSW}^{50}$

CEDAW has since won considerable praise as a tool of innovative feminist jurisprudence. The American legal scholar, Kathleen Sullivan, gives it credit for an expansive vision that sharply contrasts with the minimalist approach of traditional efforts to constitutionalize women's equality. "American constitutional law operates under strong conventions of constraint to general norms of formal equality, symmetrically interpreted, against state rather than private action, to promote negative not positive rights, that are capable of judicial enforcement," Sullivan writes. ${ }^{51}$ CEDAW, adopts an explicitly female perspective and defines inequality on women's terms, without a male default. It acknowledges genuine biological difference but also prohibits socially constructed gender stereotypes; it permits consideration of matters like maternity, childrearing, and other family obligations, but dismisses cultural tropes of physical and intellectual inferiority that have long enforced male privilege and constrained women's opportunities, such as denying women physically demanding jobs or keeping them out of the military. In this respect, she notes, as have others, that CEDAW resolves historic conflicts in how best to adjudicate between sexual difference and equality and elaborates conditions to create an equal playing field for women. Sullivan concludes admiringly that CEDAW is "asymmetric, extended to private action and positive rights, and culturally aspirational." 52

CEDAW is also celebrated for its contribution to global development theory and practice. The feminist economist, Devaki Jain, gives the women's movement credit for undertaking the critical research and making the necessary arguments to demonstrate that multiple constraints of sex, race, and class constrain economic growth, that progress does not just "trickle down." In doing so women reframed global understanding of social and economic inequalities as essential issues of human rights, or as she puts it, they "inscribed development into rights."

In 1980, Kurt Waldheim rewarded Leticia Shahani for her intellectual contributions to CEDAW, and her instrumental role in its negotiation, by appointing her as the UN's second female Assistant Secretary General for Social Development and Humanitarian Affairs, filling the vacancy left by Helvi Sipila's retirement. Five years later Shahani would oversee the Third World Conference on Women in Nairobi, Kenya, ending the so-called UN Decade on Women and earning plaudits 


\section{Ellen Chesler}

for producing an outcome document that continued to refine policy objectives and adopt "forward looking" strategies to shape programs on the ground. She also elided vocal tensions between the G77 alliance and the US government under Ronald Reagan, when the agreement nearly foundered over characterizations of "Zionism as racism," [sic] until Shahani managed to sit down with warring parties and negotiate less incendiary language to express concerns about the rights of Palestinians. ${ }^{54}$

Intending to spend a quiet Christmas holiday with her ailing father, Shahani instead returned home that year and made national headlines when she confided to a reporter that change was necessary and she would vote in the coming election for the Marcos challenger, Corazon Aquino. Marcos subsequently claimed victory despite allegations of largescale voter fraud, which led to the defections of Eddie Ramos and other senior military officials and forced him into exile.

Shahani left the UN and joined the Aquino administration as an undersecretary in the Department of Foreign Affairs, where she drafted a development plan that introduced gender analysis and programming across government agencies. She then held two, six-year terms in the Philippine Senate, passed legislation providing protection against sex discrimination and unfair workplace practices, built a vocational training and life skills program for women, and helped her brother improve family planning services in the country when he became president. In retirement, she returned to her family's home province of Pangasinan and organized a cooperative to train farmers, many of them women, in sustainable agriculture. "I'm in the grassroots now," she told an interviewer. She died in March of 2017.55

\section{Conclusion}

This history reminds us, if we need reminding, that the common characterization of women's rights as a western invention, imposed on innocents elsewhere in the world, is not only wrong but also insulting. It ignores years of commitment by the two distinctly talented individuals profiled in this chapter and by thousands of others from across the world who have assumed positions of leadership in global forums over the past half century.

They shaped laws and policies rooted in and relevant to their own experiences. They uncovered the common disadvantages women face across geographic and ideological divides - no matter what their circumstances. They framed the issue of women's rights as a moral imperative but also as a necessary condition for success in advancing prosperity and securing peace - along the way convincing a wary male establishment to take these arguments seriously. Too often, however, they became scapegoats for modernization's false promises and its discontentscondemned as disloyal to local cultures, as in Iran-their bodies made battlegrounds, as in Ghana.

Understanding that sex discrimination is deeply embedded in families and cultures, they insisted that measures be taken to abolish bias not just in the law, but also in customs and practices assuming women's inferiority that had long been 
taken for granted. They helped establish standards for legal scrutiny and protection of women's rights but also took on the challenge of changing attitudes and behaviors through education, media, and culture. Recognizing that rights cannot be realized in the absence of resources, they demanded social and economic investments to secure political freedoms and civil liberties, and they advanced the principle of indivisibility among rights categories.

Jiagge and Shahani may rightly be identified as cosmopolitan elites-wellbred and well-schooled - fluent in several languages and comfortable in often daunting situations - all necessary attributes for success as diplomats. But they also helped launch and left in place vast networks of grassroots activists, who in turn seeded local social justice work on the ground. They persisted as political and economic turmoil enveloped their home countries, confident that rights and opportunities for women are a necessary foundation for stable societies.

"What we have put in place is a revolution from which there is no turning back," Annie Jiagge proclaimed at Mexico City in 1975. "If we succeed, all humanity has a chance." ${ }^{56}$

\section{Notes}

1 Deborah Atobrah and Albert K. Awedoba, "A Trail-Blazer, An Outstanding International Jurist, A Humanitarian, An Ecumenical Christian and More: The Life of Justice Annie Jiagge (Nee Baeta)" in ed. Mercy Akrofie Ansah and Esi SutherlandAddy, Building the New Nation: Seven Notable Ghanaians Accra: Institute of African Studies, University of Ghana, 2018, 3. Also see, "Jiagge, Annie (1918-1996) in Encylopedia.com http://www.encyclopedia.com/women/ecncyclopedias-almanacstranscr Also see Josephine Dawuni. "Jiagge, Annie Ruth(1918-1996) in The Dictionary of African Biography, accessed from the Oxford African American Studies Center Https://oxfordaasc.com/view/10.1093/acref/97801953901301731.001.0001/

2 United Nations, The United Nations and the Advancement of Women, 1945-1996, United Nations Blue Book Series, Volume VI, UN Sales Publication, E.96.I.9, New York, 1996, 175.

$3 \mathrm{UN}$ and the Advancement of Women, 175.

4 Ramos-Shahani, Leticia V., interview by Richard Jolly, United Nations Intellectual History Project, New York, Columbia Center for Oral History Columbia University Rare Book Library, November 27 \&December 11, 1999, 12.

5 See, for example: Marsha A. Freeman, Christine Chinkin, and Beate Rudolf, eds., The UN Convention on the Elimination of All Forms of Discrimination Against Women: A Commentary, Oxford, UK, Oxford University Press, 2012, and SchöppSchilling, Hanna Beate, ed., The Circle of Empowerment: Twenty-Five Years of the UN Committee on the Elimination of Discrimination Against Women, New York, The Feminist Press, 2007.

6 Weiss, Thomas G., Tatiana Carayannis, Louis Emmerij, and Richard Jolly, UN Voices: The Struggle for Development and Social Justice, Bloomington and Indianapolis: Indiana University Press, 2005, 162. Lars Adam Rehof, Guide to The Travaux Preparatoires of The United Nations Convention on the Elimination of All Forms of Discrimination Against Women, Dordrecht/Boston/London, Martius Nijohoff Publishers, 1993, references the loss of documents in his introduction.

7 Arvonne S. Fraser, "The Convention to Eliminate All Forms of Discrimination Against Women (The Women's Convention"), in ed. Anne Winslow, Women, Politics and the United Nations, Westport, Connecticut, Greenwood Press, 1995, 77-94. 
8 Lars Adam Rehof, Guide to The Travaux Preparatoires, 3. The guide contains the original Philippine draft, the joint Philippine/USSR draft and as much documentation as exists in Geneva on the debate over specific articles.

$9 \mathrm{UN}$ and the Advancement of Women, 29,173.

10 Fraser, "“"The Convention to Eliminate All Forms of Discrimination Against Women (The Women's Convention"), 80-81. Others among those present in Tehran were Helvi Sipila of Finland, Aziza Hussein of Egypt, Jeanne Chaton of France, Helena Benitez of the Philippines, Zofia Dembinska of Poland, Hannah Bokor of Hungary, Rachel Nason of the U.S., and Ashraf Pahlavi, along with representatives of UN technical agencies and from 22 NGOs. For background on Iran, also see a timeline prepared by the Foundation for Iranian Studies, https://fis-Iran.org/en/women/milestones/ pre-revolution. Pahlavi pops up occasionally in UN archives. See for example, a cable dated October 25, 1971 with birthday wishes from Secretary General, U Thant in UN Archives in New York.

11 Fraser, "The Convention to Eliminate.", 80-81. For Articles 3 of the ICCPR and ICESR, see UN and the Advancement of Women, 174.

12 Arvonne Fraser, "The Convention to Eliminate," 82-83. Fraser's notes are sparse but reference UN, ECOSOC, $39^{\text {th }}$ Session, Official Records, Supplement 7; CSW, Report on the $18^{\text {th }}$ Session (1-10-March 1965, 23 and UN ECOSOC, and a CSW report on the $18^{\text {th }}$ session (March 1-10, 1965) for her account.

$13 \mathrm{UN}$ and the Advancement of Women, 30, 175-176.

14 Biographical detail on Jiagge is from Atobrah and. Awedoba, Life of Justice Annie Jiagge, 8-15. Also see Abe and Edith Halperin, "It's Wonderful to Be a Woman: An Interview with Annie Jiagge," The Rotarian," February, 1968, 36-38, and Seth Bokpe, https://www.theghanareport.com/she-called-the-bluff-of-chauvinists-to-becomeghanas-first-female-lawyer-judge/ Kate Skinner, "Women's rights as international human rights: Justice Annie Jiagge of Ghana," Birmingham Blogs, https://blog.gham. ac.uk/archiveofactivism/2019/07/23/womens-rights-as-international-hum-aightsjustice-annie-jiagge-of-ghana/. Fred Jiagge had also been a teacher but then went to work for the Tema Development Corporation, an urban real estate development firm originally chartered in 1952 before independence. Atobrah and. Awedoba, Life of Justice Annie Jiagge, 15.

15 Adwoa Kwakyewaa Opong, "Rewriting Women into Ghanaian History, 1950-63" (Master's Thesis: University of Ghana, 2012), 30-53. Ms. Opong went on to pursue her Ph.D. at Washington University in St. Louis. Also see, Dennis Austin, Politics in Ghana, 1948-1960 (New York: Oxford University Press, 1965). Also see, Naaborko Sackeyfio-Lenoch, "Women's International Alliances in an Emergent Ghana,"Journal of West African History 4, no 1 (Spring, 2018).

16 Opong, 67-68.

17 Opong, 72.

18 Opong, 72-74, with the quote on p. 75.

19 Opong, 72-74, with the quote on $\mathrm{p} 75$. Opong found the remarks in private archives of Dr. Evelyn Amarteifio of the the Ghanaian Organization of Women, held at the Department of History, University of Ghana, Legon. Jiagge's quoteon "civic death" is from Annie R. Jiagge, "Exploitation of Women in Third World Perspective," The Ecumenical Review, Fall, 1976, 42.

20 Opong, 75. The most contentious debate of the gathering, however erupted over race, not gender, when a delegate proposed a resolution condemning both the United States and South Africa for their oppression of people of color. Murray and others beat back the measure by distinguishing America's constitutional system from apartheid on the grounds that the U.S. government had intervened in the federal courts to overturn state sanctioned segregation policies. See Rosalind Rosenberg, Jane Crow: The Life of Pauli Murray (New York: Oxford University Press), 2017, 227-228.

21 Rosenberg, 229-239. 
22 Rosenberg, 244-252, 287-289308-309, 385-388. In an email exchange with the author, Rosenberg said she was able to find only one piece of correspondence about the conference in Murray's papers which reflects her concern about the anti-Americanism expressed there and says nothing about women's rights.

23 Annie R. Jiagge, "Exploitation of Women in Third World Perspective," The Ecumenical Review, Fall, 1976, 42.

24 Annie R. Jiagge, "Exploitation of Women in Third World Perspective," The Ecumenical Review, Fall, 1976, 42-48.

25 Atobrah and. Awedoba, Life of Justice Annie Jiagge, 28-30.

26 Atobrah and. Awedoba, Life of Justice Annie Jiagge, 16, 35. For more on Women's World Banking and Jiagge, see Margaret Snyder and Mary Tadesse, African Women and Development, Zed Books, London, 1995, and Michaela Walsh, Founding A Movement, Women's World Banking, 1975-1990, (New York: Cosimo Books, 2012), 11, 94-96. Also see Annie Jiagge, "Letter to Mildred Persinger, December 13, 1977," Mildred E. Persinger papers, 106, Hollins University, https://digitalcomons.hollins. edu/persinger-papers/106.

27 Atobrah and. Awedoba, Life of Justice Annie Jiagge, 26-28, 30. On the 1992 constitution, https://dailyguidenetwork.com/work-committee-experts-1992-constitution/

28 "Tribute by the United Nations Secretary-General, Dr Boutros Boutros-Ghali, memorial for Mrs. Justice Annie Ruth Jiagge, 3 August 1996, http://www.un.org/ women'swatch/daw/news/jiagge.htm

29 Leticia Shahani, "The UN, Women, and Development: The World Conferences on Women", in Developing Power: How Women Transformed International Development, (New York: The Feminist Press, 2004) 29. Shahani, Oral History, 12-14. When asked to identify outstanding women from this period, Shahani named Annie Jiagge among others, noting that the Soviet women were also exceptional but that their governments never stood behind them - their legal rights were never realized, nor would the USSR ever spend money to support the women's agenda at the UN.

30 Roland Burke, "Confronting 'Indivisibility' in the History of Economic and Social Rights: From Parity to Priority and Back Again," review of Indivisible Human Rights by Daniel Whelan, Human Rights \& Human Welfare, 12, 2012, 61.

$31 \mathrm{UN}$ and the Advancement of Women, "Resolution IX adopted by the International Conference on the Human Rights in Tehran on measures to promote women's rights in the world and endorsing the Secretary-General's proposal for a unified long-term United Nations programme for the advancement of women," May 12, 1968, 117, and "General Assembly resolution outlining a programme of concerted international action for the advancement of women", December 15, 1970, 179.

32 A formal letter dated January 27, 1969 from Philippine Ambassador Privado Jimenez announcing Shahani's appointment is one of the few references I was able to find to her in the UN CSW archives in New York.

33 Biographical details are from Shahani, Oral History, 1-2; Elena Masilungan, "Leticia Ramos-Shahani, Diplomacy and initiative in and of the UN," Shaping the Women's Global Agenda: Filipino Women in the United Nations, ed. Olivia H. Tripon (Manila: National Commission on the Role of Filipino Women, 2007), 17-35; "Leticia Ramos-Shahani, "Be Strong Because You Are A Woman!" interview by Melvin C, Almonguera, in Frontlines of Diplomacy: Conversations with Phillipine Ambassadors, ed. J. Eduardo Malaya, (Manila, Anvil Publishing, 2011),197-199. My thanks to Patricia Licuanan, Filipino representative to the CSW and its chair during the 1995 World Conference on Women in Beijing, for copies of these publications. Also see Michael Bueza, "Leticia Ramos Shahani, 1929-2017, The woman who competed with the best," https://www.rappler.com/nation/164671-letitia-ramos-shahaniobituary. A short biography of Fidel (Eddie) Ramos is at www.Britannica.com/print/ article/490745.

34 A bibliography and some biographical detail for Ranjee Gurdassing Shahani is at www.open.ac.uk/researchprojects/makingbritain/content/ranjee/g/shahani. 
35 Author's interview with Lila Shahani in New York City, February 16, 2020. Also see Lila's eulogy of her mother at https://www.rappler.com/thought-leaders/165203-lifeshahani-eulogy-leticia-ramos-shahani.

36 Author's interview with Lila Shahani in New York City, February 16, 2020.

37 Shahani Oral History, 12.

38 Shahani Oral History, 5-7.

39 Author's interview by phone with Mina Falcon in Calgary, Canada, October 12, 2020. Also see Minerva Jean Abuyuan Falcon, interview with Nomer Blevins, in Frontlines of Diplomacy. Freeman and Chinken, "Introduction," in The UN Convention on the Elimination of All Forms of Discrimination Against Women: A Commentary, 2-3, 8-9.

40 Author's interview by phone with Mina Falcon in Calgary, Canada, October 12, 2020. Also see Minerva Jean Abuyuan Falcon, interview with Nomer Blevins, in Frontlines of Diplomacy. Freeman and Chinken, "Introduction," in The UN Convention on the Elimination of All Forms of Discrimination Against Women: A Commentary, 2-3, 8-9.

41 Author's interview with Falcon.

42 Shahani in Shaping the Global Women's Agenda, 25-26; Shahani in Developing Power, 31-32.

43 Jocelyn Olcott, International Women's Year: The Greatest Consciousness-Raising Event in History, (2017), New York: Oxford University Press.

44 Jocelyn Olcott, International Women's Year: The Greatest Consciousness-Raising Event in History, (New York: Oxford University Press, 2017). Also see Ellen Chesler, "The Year of the Woman Again," review of Olcott, The Women's Review of Books 35, no 5, September-October, 2018. And for a competing view, see Roland Burke, "Competing for the Last Utopia? The NIEO, Human Rights, and the World Conference for the International Women's Year, Mexico City, June 1975", Humanity, 26, Spring, 2015, 47-61. INSTRAW got underway with a grant from Iran and was meant to be housed in Tehran, but was relocated to the Caribbean.

$45 \mathrm{UN}$ and the Advancement of Women, "General Assembly resolution calling on State Parties to ratify international conventions and other instruments concerning the protection of women's rights... and requesting the CSW to complete the draft convention on the elimination of discrimination against women." 217.

46 Rehof, "Introduction to the Genesis of the Convention," Guide to The Travaux Preparatoires, 6-12.

47 Rehof, Guide to The Travaux Preparatoires, 15.

48 The UN and the Advancement of Women, "Convention on the Elimination of all Forms of Discriminatiion against Women, adopted by the General Assembly on 18 December 1979", 244. Rehof, Guide to The Travaux Preparatoires, 66-69. Freeman and Chinken, "Introduction," in The UN Convention on the Elimination of All Forms of Discrimination Against Women: A Commentary, 8-9.

49 Rehof, Guide to The Travaux Preparatoires, found the most records and provides its most extensive documentation of treaty deliberations on Article 16, owing no doubt to it's the controversial ground it covers, 168-186. Freeman and Chinken, "Introduction," in The UN Convention on the Elimination of All Forms of Discrimination Against Women: A Commentary, 10-11.

50 Rehof, Guide to The Travaux Preparatoires, as throughout, only identifies comments by country, not by individual. His discussion of Articles 17-21 on implementation is extensive, 187-223. Perhaps not surprisingly, USSR delegates wanted no committee. Also see, Arvonne S. Fraser, "Making History Word for Word," Journal of Women's History, 24, no 4, 193-200. Koryn Horbel's interest in strong monitoring was first expressed in a statement she made on April 2, 1978 published by the U.S. Mission to the UN, a copy of which was given to the author. Horbel's papers are collected at the Minnesota Historical Society in Minneapolis but not available online. Iran's concerns are notable, as this was, of course, a final intervention for representatives of the Pahlavis. 
51 Kathleen M, Sullivan, “Constitutionalizing Women's Equality" California Law Review, 90 (3), 762.

52 Kathleen M. Sullivan, "Constitutionalizing Women's Equality," California Law Review, 90, no. 3, May, 2002, 735-764, with the quote on 762. At: http://www.jstor. org/stable/3481236.

53 Devaki Jain, Women, Development, and the UN: A Sixty-Year Quest for Equality and Justice, Indiana University Press, Bloomington and Indianapolis, 2005, 33.

54 Shahani in Shaping the Global Women's Agenda, 27-29. Shahani's appointment was treated as a big deal at the UN. See "LETICIA R. SHAHANI APPOINTED ASSISTANT SECRETARY GENERAL FOR SOCIAL DEVELOPMENT AND HUMANITARIAN AFFAIRS," UN Press Release, Department of Public Information, UN, New York; Kurt Waldheim to Shahani, January 16, 1981; Ambassador Alejandro D. Yango to Kurt Waldheim, transmitting the appreciation of Carlos P. Romulo, then Philippine Minister for Foreign Affairs, September 10, 1980, all in the Waldheim papers, UN Archives, New York.

55 Shahani in Shaping the Global Women's Agenda, 2-34. Shahani's name was raised as a qualified woman to become Secretary General when Kofi Annan got the job in 1996. See Roberto Ordonez, "Etcetera, Etcetera: 'Miss UN' Shahani a good bet for Sec-Gen at https: //search-proquest-com/docview/367855301? Also see Steven Erlanger, "Manila Journal: From a Life of Privilege, a Woman of Substance," The New York Times, November 9, 1989. Jennifer Jett, "Overlooked No More: Leticia Ramos Shahani: a Philippine Women's Rights Pioneer, The New York Times, June 4, 2018.

56 Annie Jiagge quoted in Jain, Women, Development, and the UN, 68.

\section{Bibliography}

Almonguera, Melvin. "Be Strong Because You are a Woman.” In Frontlines of Diplomacy: Conversations with Philipine Ambassadors, edited by J. Eduardo Malaya. Manila: Anvil Publishing, 2011.

Atobrah, Deborah, and Albert K. Awedoba. "A Trail-Blazer, An Outstanding International Jurist, A Humanitarian, An Ecumenical Christain and More: The Life of Justice Annie Jiagge (Nee Baeta)." In Building the New Nation: Seven Notable Ghanians, edited by Mercy Akrofie Ansah and Esi Sutherland-Addy. Accra: Institute of African Studies: University of Ghana, 2018.

Austin, Dennis. Politics in Ghana, 1948-1960. New York: Oxford University Press, 1965.

Burke, Roland. "Competing for the Last Utopia? The NIEO, Human Rights, and the World Conference for the International Women's Year, Mexico City, June 1975." Humanity 26 (2015): 47-61.

Burke, Roland. "Confronting "Indivisibility" in the History of Economic and Social Rights: From Parity to Priority and Back Again', Review of Indivisible Human Rights by Daniel Whelan." Human Rights \& Human Welfare 12 (2012).

Chesler, Ellen. “"The Year of the Woman Again', Review of Olcott.” The Women's Review of Books 35, no. 5 (2018): 25-27.

Fraser, Arvonne S. "Making History Word for Word." Journal of Women's History 24, no. 4 (2012): 193-200.

Fraser, Arvonne S. "The Convention to Eliminate All Forms of Discrimination Against Women (The Women's Convention)." In Women, Politics and the United Nations, edited by Anne Winslow. Westport; Conneticut: Greenwood Press, 1995.

Freeman, Marsha A., Christine Chinkin, and Beate Rudolf, eds. The UN Convention on the Elimination of All Forms of Discrimination Against Women: A Commentary. Oxford, UK: Oxford University Press, 2012. 


\section{Ellen Chesler}

Halperin, Edith, and Abe Halperin. "It's Wonderful to Be a Woman: An Interview with Annie Jiagge." The Rotarian February (1968).

Jain, Devaki. Women, Development, and the UN: A Sixty-Year Quest for Equality and Justice. Bloomington: Indiana University Press, 2005.

Jiagge, Annie R. "Exploitation of Women in Third World Perspective." The Ecumenical Review Fall (1976).

Kwakyewaa Opong, Adwoa. "Rewriting Women into Ghanaian History, 1950-63." Master's Thesis, University of Ghana, 2012.

Masilungan, Elena. "Leticia Ramos-Shahani, Diplomacy and Initiative in and of the UN." In Shaping the Women's Global Agenda: Filipino Women in the United Nations, edited by Olivia H. Tripon. Manila: Anvil Publishing, 2007.

Olcott, Jocelyn. International Women's Year: The Greatest Consciousness-Raising Event in History. New York: Oxford University Press, 2017.

Rehof, Lars Adam. Guide to The Travaux Preparatoires of The United Nations Convention on the Elimination of All Forms of Discrimination Against Women. Dordrecht; Boston; London: Martinus Nijhoff Publishers, 1993.

Rosenberg, Rosalind. Jane Crow: The Life of Pauli Murray. New York: Oxford University Press, 2017.

Sackeyfio-Lenoch, Naaborko. "Women's International Alliances in an Emergent Ghana." Journal of West African History 4, no. 1 (2018): 27-56.

Schöpp-Schilling, Hanna Beate, ed. The Circle of Empowerment: Twenty-Five Years of the UN Committee on the Elimination of Discrimination Against Women. New York: The Feminist Press, 2007.

Shahani, Leticia. "The UN, Women, and Development: The World Conferences on Women." In Developing Power: How Women Transformed International Development. New York: The Feminist Press, 2004.

Snyder, Margaret, and Mary Tadesse. African Women and Development. London: Zed Books, 1995.

Sullivan, Kathleen M. “Constitutuonalizing Women's Equality.” California Law Review 90, no. 3 (2002): 735-764.

United Nations. "The United Nations and the Advancement of Women, 1945-1996." United Nations Blue Book Series. New York: UN Sales Publication, 1996.

Walsh, Michaela. Founding A Movement, Women's World Banking, 1975-1990. New York: Cosimo Books, 2012.

Weiss, Tom, and Pallavi, Roy. "The UN and the Global South, 1945 and 2015: Past as Prelude?" Third World Quarterly 37, no. 7 (2016): 1147-1155.

Weiss, Thomas G., Tatiana Carayannis, Louis Emmerji, and Richard Jolly, UN Voices: The Struggle for Development and Social Justice, Bloomington and Indianapolis: Indiana University Press, 2005. 